\title{
Altruistic Relationships, Responsibility, and Sociology: An Attempt at Theoretical Systematization
}

\author{
Emiliana Mangone ${ }^{1}$ (i)
}

Accepted: 1 November 2021/Published online: 9 November 2021

(C) The Author(s), under exclusive licence to Springer Science+Business Media, LLC, part of Springer Nature 2021

\begin{abstract}
The book Beyond the Dichotomy Between Altruism and Egoism (Mangone in Charlotte, NC: Information Age Publishing Inc., 2020a) raised compelling comments by distinguished scholars. Some of them were, in my opinion, particularly poignant, highlighting both strengths and weaknesses of the elements addressed in the book. I aim to answer the remarks by Roberto Cipriani, Estrella Gualda, Ratiba Hadj-Moussa, Adrian Scribano, and Nikolay Zyuzev. I will leave the strengths aside and focus instead on the aspects that most attracted the reflections of the commentators, which I can summarise in three macro areas: 1) the centrality of the relationship; 2) responsibility and choices; and, finally, 3) the role of sociology. I will attempt to get to the heart of these areas with a theoretical systematization, providing a general answer to the remarks as well as addressing the specific points raised by each commentator.
\end{abstract}

Keywords Altruism · Relationship · Ethics of Responsibility $\cdot$ Choice $\cdot$ Sociology · Positive sociology

Writing a book is always a meditated and troubling choice. Deciding to draft Beyond the Dichotomy Between Altruism and Egoism (Mangone, 2020a) may have been a form of academic isolation - or even masochism. It is particularly true in Europe where, excluding the research and studies proposed by the scholars of the Mouvement Anti-Utilitariste dans les Sciences Sociales (MAUSS) ${ }^{1}$ in France, this topic is almost totally absent - it is, however, much stronger in the United States and Latin

\footnotetext{
${ }^{1}$ The acronym is not accidental. The main promoters (Gérard Berthoud, Alin Caillé, Jaques T. Godbout, Jean-Louis Laville, Serge Latouche and Guy Nicholas) wanted to highlight their esteem for the French scholar Marcel Mauss and their strong link with his thought.
}

Emiliana Mangone

emangone@unisa.it

1 Department of Political and Communication Sciences, University of Salerno, Via Giovanni Paolo II, 132, 84084 Fisciano, SA, Italy 
America (see Jeffries et al., 2006; Nichols, 2012). The last century was still rolling when Sorokin (1966) pointed out that the social sciences, particularly sociology, seemed focused on negative phenomena rather than positive ones - such as altruism, cooperation, solidarity, et similia. Today, this modus operandi does not seem much changed, despite the pandemic-induced crisis - due to the spread of the SARS$\mathrm{CoV}-2$ virus - whose global fallout requires collective responses.

The above-mentioned book met with generous interest and received several reviews (Maldonado, 2020; Zyuzev, 2020; Guadarrama-González, 2021). Their thought-provoking content compelled me to further fuel the debate with some colleagues who offered criticisms and suggestions. I wish to thank Roberto Cipriani (Italy), Estrella Gualda (Spain), Ratiba Hadj-Moussa (Canada), Adrian Scribano (Argentina), and Nikolay Zyuzev (Russian Federation), and Lawrence Nichols who, as Editor-in-Chief, took on the task of organising the symposium and guiding us through all the journal procedures.

The essays reveal both strengths and weaknesses in some of the essential features discussed in the book. Leaving aside the strengths, I will focus on the elements that most attracted the commentators' interest as aspects to be further explored or clarified. I can summarise them in three macro areas: 1) the centrality of the relationship (Roberto Cipriani, Ratiba Hadj-Moussa, and Adrian Scribano); 2) responsibility and choices (Estrella Gualda and Nikolay Zyuzev); and, finally, 3) the role of sociology (Estrella Gualda). In the following pages, I will try to get to the heart of these fields and attempt a theoretical systematization. I will offer both a general response and answer specific points raised by the commentators.

\section{Relationships as Reciprocity Between Individuals}

The lead-off is that, in contemporary society, we must consider altruism and egoism as unhooked from the elements that tied them (almost) exclusively to either human nature or mere economic aspects (Mangone, 2020b). Their role in everyday life and individual subjectivity needs further investigation to better explain and understand both their dynamics and outcomes. And yet, not all individuals or communities can activate capacities to respond (reflection) to situations that require altruistic relationships. The term "activation" underscores the subject's active role in determining the causes or premises of events that affect behaviour. Speaking of "pro-action", which becomes pro-social behaviour if it refers to others - as mentioned by Cipriani (2021), means acknowledging that even the very possibilities for action offered by the social context ultimately fall under individual responsibility. Individuals often opt for re-action rather than pro-action, due to the absence or scarcity of those social relations that birth the processes of reflexivity allowing for conscious and responsible decision-making.

I believe that one should not speak of altruism or egoism but of relationships that can be altruistic or egoistic. To better clarify this, I will try to construct a theoretical model by applying Douglas (1970) two-dimensional grid-group model: autonomy/ subordination and individual/community. The model was created to order the logics adopted by groups and social groups regarding risk (Douglas \& Wildavsky, 1983; 
Schwarz \& Thompson, 1990; Thompson et al., 1990). However, one can apply it to the altruism/egoism dichotomy by founding it on reflexivity (May \& Perry, 2017). This attempt to deconstruct - or, better, decompose - the relationship is crucial because we cannot study altruism by focusing solely on individual personality. Every action with positive or negative effects is nothing more than a form of interaction and, therefore, of social relationship between two or more parties - There is an I, a You, a We, and a They. I partly agree with Scribano when he says that a social relationship begins when "I" becomes "you" for another because that means being recognised. Therefore, at the basis of the relationship, there is always the recognition of each person as the other.

The cultural-symbolic approach I adopted throughout the book links lifeworld and social system, promoting a relationality-based interaction between individuals. It is no coincidence that, in my adaptation (Mangone, 2020a, p. 150) of Griswold's diamond (1994, p. 15), the Lebenswelt (lifeworld) takes the place of the social world - as highlighted at length by Cipriani. Social relationships produce added value by constituting themselves as reciprocal actions (between individual actors or collective actors) that breed the order of reality (shared social space). The latter requires a negotiation between human subjectivity and social systems or, better, between the various means offered by the social system to achieve the goals that refer to the cultural system (Merton, 1968). Reflexivity is related to the order of reality of the social relationship. It is a guide to close this cycle with structural elaboration and reproduction. It is neither subjective nor structural - nor is it enough for producing knowledge on what individuals do, think, and experience in a relational context. This knowledge is an emerging effect of the interaction between specific forms of doing and being of individuals; it bolsters the trust that leads to the construction of relationships between individuals in a hetero-directional perspective. Reflexivity allows individuals to orient themselves about the reality emerging from their interactions, which can reflect on themselves since it transcends the powers of individuals and/or the collective. Reflexivity is necessary for the structural and symbolic mediation between means/goals, and between the doing/being of individuals by combining self- and hetero-perception. Furthermore, social relationships are affected by the autonomy/subordination and individual/community factors in the grid-group model. These features determine the different forms of social organization to which correspond distinct forms of recognition.

Reflexivity constitutes the phase in which all the interacting elements elaborate and structurally reproduce the significant interactions linked to a condition that generates - or at least can generate - altruistic relationships or egoistic relationships based on the creation of conditions of trust (Gambetta, 1988; Fukuyama, 1995) or distrust (Mutti, 2007). The construction process of trust conditions involves both the social and the individual dimension. On the one hand, cultural and ethical changes increasingly distance individuals from common and shared goals and objectives (generated by individualistic and markedly competitive approaches). On the other hand, individuals experience continuous changes, suffering their consequences without being their prime architects - see Beck (1994) when he stresses the aspects that characterize the individualization of human life. Therefore, to engage with others is mainly to bet on their positive action and attribute trust, from which descend the 
altruistic relationships (altruism, solidarity, cooperation, gratitude, gift, etc.). Otherwise, one will attribute distrust, generating egoistic relationships (selfishness, utility, competition, ingratitude, etc.).

In my book, I raised the following question: Is it possible to reach conditions that foster trust and, consequently, altruistic relationships? The optimistic answer is yes. However, further investigation is needed, not least to address Ratiba Hadj-Moussa's remark that I overlooked the role of institutions and some aspects of Durkheim's division of labour (Hadj-Moussa, 2021).

How can one guarantee these necessary conditions? The answer is twofold. First, by mobilizing the resources, relationships, and opportunities that the social actor can express. The social actor "is not someone who acts in accordance with the position he occupies, but someone who modifies the material and, above all, social environment in which he finds himself by transforming the division of labour, modes of decisionmaking, relations of domination or cultural orientations" (Touraine, 1995/1992, p. 208). A partial answer to Hadj-Moussa's criticism is thus this: social actors are the main characters in these transformations, and they can be anyone, regardless of their role in the division of labour (they could equally be a teacher or a worker). Second, through social capital (Coleman, 1990), referring to the social context and a change in the relationships between individuals to facilitate action. Social capital consists of processes of informal and formal reciprocity; they follow rules that define the form, content, and boundaries of exchanges. The relationships are the product - intentional or unintentional - of social investment strategies aimed at the constitution and reproduction of long-lasting social ties that can provide material and symbolic profits. Both Zyuzev (2021) and Gualda (2021) offered examples, the former with the protest movements in Russia and the latter with the reception of refugees in Mediterranean countries.

It follows that the altruistic relationships develop when exchanges aim at the continuous search for well-being in a situation of consciousness and responsibility - individual and collective. In this way, altruistic relationships are no longer an abstract concept. They become a social place originating reciprocity between individuals. Such reciprocity stems from reflexivity, which promotes trust and bears towards the common good. Individual attitudes, however, are not always positively oriented towards others. Indeed, diversity is often considered not a resource but a constraint on everyday life and a threat to the future (mistrust). These conditions of mistrust are pivotal for the processes of symbolic mediation and identity negotiation (Dubar, 2003). Therefore, they are also paramount in the life project of individuals. Education and socialisation processes take on a central role: through them, we gain positive reassurance in imagining our future in reciprocity with others.

\section{Beyond the hic et nunc: The Ethics of Responsibility}

When looking closely at the above-described processes, one cannot but lose any previous belief that the market is the primary cause of stable relationships within a community. Social capital has an inherent interpretation of holistic development 
insofar as it does not stop at economic aspects but directly involves individuals, stimulating their central role through actions that lead to sharing a path to achieve a common objective.

The cultural-symbolic model that I employed for the social construal dynamics of altruism and egoism goes beyond the economic and naturalistic logic that previously marked the study of these interactions (see the theory of rational choice suggested by Zyuzev). However, this model acknowledges that individual attitude can be active (doing something) and responsible (choice and attribution of blame). In other words, not to have too rigid an interpretative model, we need a structure that ensures accountability, evidence-based practice, and action that in the long term guarantees a balance between goals and means. These are priority aspects, as altruistic relationships rest mainly on the trust and consensus that the community, often opposed to the political system, can still claim to have within society.

Every society establishes its hierarchy of values. However, the perceptions underpinning its construction may not correspond to measurable values, nor represent individual decisions. Nowadays, attention has moved towards quality-of-life related needs, due to both the influence of the mass media and the general increase in wellbeing (Mangone, 2017). We thus shift from an approach reducing actions to mere economic aspects to one focused on the overall interactions between all relevant variables (economic, social, and cultural). Actions are deflected from rational choice to be oriented instead towards solidarity-based efforts. The theory of rational choice does not apply in connection with the future because it relies on the hic et nunc. One looks at the present or, at most, to possible perspectives in the near future. The everyday environment of an individual experiencing a health-related emergency - as in the case of the COVID-pandemic - is divided into distinct problems. "The ability to acquire knowledge on the surrounding situations and the environment is necessary both to facilitate the creation of alternatives and to estimate the possible consequences, allowing the individual to preserve the image of that part of the world involved in her decisions. The individual, then, sets her decisions (and her actions) based on that image. Her choices should not aim at her personal well-being but at that of every individual in the community" (Mangone, 2021, p. 5). Crisis prompts the individual "to continue its predatory policies of individual and tribal selfishness that lead it to its inevitable doom, or to embark upon the policies of universal solidarity that brings humanity to the aspired for heaven on the earth. It is up to every one of us which of the two roads we prefer to choose" (Sorokin, 1954, p. 489). This is where what I call the ethics of responsibility comes in. Almost all commentators interpreted this concept differently: Cipriani quotes Ricœur (1992/1990), reiterating the relationship between identity and time; Estrella Gualda refers to the institutional responsibility of governmental and non-governmental bodies; Scribano censures the failure to overcome the Weberian vision of responsibility and, finally, Zyuzev argues that the theory of rational choice seems to respond well to the demands of the ethics of responsibility. Ethics, which has marked the lives of human beings since ancient times, is the set of objective and rational foundations that make it possible to distinguish human behaviour into good, just, or morally licit on the one hand and evil or morally inappropriate on the other. These principles, or their pursuit, are usually divided into secular and religious (chiefly Christian), allowing individuals to 
manage their freedom, especially its limits - to avoid infringing the right to existence of other beings. Contrasting secular ethics with religious ethics on issues related to altruism and/or egoism would thus be superficial. I will, therefore, refrain from speculation and conjecture based on such opposition, which would result in an approximate, worthless picture. Hence the need for public ethics, and specifically the ethics of responsibility. It relies neither on individual morality nor on collective ethics (secular or religious) but represents the vision of the world that is being transformed.

"The ethics of responsibility is far removed from both hyper-subjectivism and objectivism. It seeks intersubjective and intercultural values that help the dialogue between the different positions aimed at the collective good" (Mangone, 2020a, p. 183). Everyone can follow the ethics of responsibility and thus guarantee the collective good. The problem is that all moral rules know exceptions, hence the need to identify the dominant behavioural principle among the conflicting ones. A new contrast thus emerges between the Kantian principle of "never to use other people merely as means to an end, but always also as ends", and the utilitarian idea spurring people to always choose "actions that maximize their utility and happiness".

Going beyond Weber's interpretation of this conflict (Weber, 1919) and considering the role of institutions, we can frame the question in terms of negotiation between individual freedom and responsible freedom. This, however, presupposes the correct application of vertical and horizontal subsidiarity - where the former exists between institutions and the latter between institutions and civil society (individual and collective subjects). Institutions (local, national, and international) have direct obligations and responsibilities and must guarantee the principles of solidarity among citizens, supporting civil society and connecting individual and collective responsibilities. At the same time, they must adequately supervise the system, guaranteeing impartiality and completeness of the interventions and services in the territory. In the case of the COVID-19 pandemic, this latter role was markedly disregarded. Individuals had to manage the emergency on their own, while the government called for solidarity. This situation suggests the negotiation between individual freedoms and responsible freedoms, where the incentives towards self-realization cannot exist outside the commitment to each other and the community as a whole. If we consider human beings as social animals, we can state that the ethics of responsibility allows individuals to recognize themselves in the concept of the common good. The latter, in turn, is something that they experience as members of a community and that they can only pursue from the standpoint of solidarity. The reference to Aristotle is almost inevitable. For the philosopher, the main ethical virtue is justice, to which he dedicates an entire book in The Nichomachean Ethics (2009). Justice is not only a whole and perfect virtue, but also has its specific meaning: it is distributive or commutative. The latter refers to questions of distributive justice, and, specifically, to reconsidering the close link between bioethics and biojurisprudence in the allocation of resources at both the macro and micro level. The relationship 
between rights and duties has a twofold reading. On the one hand, it translates into an inter-individual relationship of commutative justice ${ }^{2}$. On the other, it is a social relationship of distributive justice of resources and goods.

Following the ethics of responsibility means that individuals must accept the consequences of their actions (for good and evil) towards themselves and others. Their responsibility is irrespective of proximity in time and/or space. Tracing back the altruist or selfish conduct of human beings to a single general principle is, thus, a failed approach. Indeed, the idea of responsibility for choices in contemporary society has too often been abdicated to law and reduced to a simple procedure rather than being an ethic of responsibility where there are no lay or religious people, believers or non-believers but simple citizens of a community. From this perspective, communities have an intrinsic holistic concept of development that goes beyond mere economic aspects and depends on the degree of civicness (Putnam, 1992) and freedom of the community - and, above all, to correct behaviours based on trust. All these elements trace back to belonging and reciprocity.

\section{From Amitology to Positive Sociology}

I have come to the last area mentioned in the introduction: the role of sociology and its modus operandi. On the function of the social sciences, I wrote: "Change must begin with the rediscovery of the positive values of man, and science is also seen as a guide through the overcoming of strictly sensate (sensory) models of knowledge. The social sciences are not merely the "sciences of the crisis": they are critical sciences, not limited to the analysis of the degenerative processes of society but that seek their deep roots by denouncing the negative factors causing them. Applying these principles implies understanding the mechanisms through which human beings make their decisions. These dynamics highlight the issue of the choice. The latter, in turn, must be specified according to the temporal dimension and degree of knowledge of situations, as well as to who takes decisions and how." (Mangone, 2020a, p. 186). Sorokin's faith in the potential of the social sciences as guides for humanity was such that he hypothesized the birth of a new applied science - amitology ${ }^{3}$ (Sorokin, 1951) - that would deal with the promotion of friendship, unconditional love, and mutual aid. While I fully share his viewpoint, I also agree with Estrella Gualda when, in her essay, she posits the sociological imagination (Mills, 1959) as a valuable tool. In her opinion, it could offer new solutions not only to post-emergency crises resulting from

\footnotetext{
${ }^{2}$ Under individualism, it means a justice that controls the execution of exchanges, transactions and contracts between free individuals while minimising the intervention of society and/or the state.

3 The first task of this new discipline would be an accurate analysis of the main aspects, properties and elementary forms of altruistic relation, which means that amitology starts from the study of social relations and interactions. At the heart of amitology are two complementary ideals: 1) an anthropological end, which aims to discover the most efficient techniques for the altruistic transformation of the human personality, and 2) a social ideal, aimed at rebuilding humanity as a universal community of altruistic love (Rusu, 2018).
} 
humanitarian catastrophes, natural disasters, or armed conflicts but also to other social problems of everyday life. It is in this sense that sociology could contribute to the development of amitology - together with psychology, biology, anthropology, and the other social and human sciences as an interdisciplinary field.

Research cannot solely provide scientific research on the topics in question: it must also constitute a mechanism for facilitating and accompanying social innovation in terms of tools, organisation, and governance of social processes (Mangone, 2020c). Social science methods do not merely reproduce the phenomena they study but contribute, to a greater or lesser extent, to their construction. Research activities are developed through methodologies that collect and study data and information; they seek to produce usable knowledge for the support, activation, reflection, and consolidation of processes of institutional innovation and individual and collective empowerment. Sorokin's idea to birth an applied science such as amitology might seem fanciful - and yet, on closer inspection, it is not, particularly if we focus on attaining engaged sociology. This should project the pursuits of sociologists and other social science researchers towards positive social transformations. In other words, we need to found sociology anew as positive sociology - not to be confused with positivist sociology - in analogy to positive psychology, as Nichols $(2005,2012)$ has pointed out. This new sociology "can describe alternative resources of preserving the social order and show how to build a good society. The main methodological principle of positive sociology is its focus on positive social phenomena that can make societal life better." (Mangone \& Dolgov, 2020, p. 8). In this case, sociological research relates to the study of pro-social phenomena - such as altruism, mutual aid, voluntary work, social solidarity, friendship, neighbourhood ties, etc. Such phenomena are not usually considered problematic (negative) aspects of society but rather regular features of human and social affairs.

It is to be hoped, therefore, that sociological knowledge will abandon the excessive self-referentiality that pens all knowledge within its own frames of reference and paradigms. It should become reflexive knowledge, capable of promoting the construction of connections in the living environments of subjects and between subjects, overcoming Comte's "social physics" to lay the (theoretical/empirical) foundations for interventions that can bring about positive transformations at both an individual and social level. According to some scholars, the ongoing changes in society, which is moving more and more towards globalisation, face sociology with a challenge that raises two types of issues (Ossewaarde, 2007). On the one hand, worldwide integration represents a threat to both citizenship and the new sociology; on the other hand, one can glimpse new possibilities for returning sociology to the "public" of world citizenship, calling for its "reinvention" in the form of a "new sociological imagination" (Fuller, 2006; Solis-Gadea, 2005). This is mainly because the processes of globalisation have not fostered the humanitarian ethos that aims at understanding between two individuals in action (relationship), who relate to each other and act taking into account their mutual intentions, motivations, and expectations. There has been no shift from an approach that reduces the actions of individuals to mere exchange (do ut des, see rational choice theory) to one that pays attention 
to the overall interactions between the elements that characterise exchange and all the other social and cultural variables.

This paradigmatic transformation demanded of sociology does not mean that social researchers must build sociological humanism but humanistic sociology, whose aim is to transform how human beings interact. This new-fangled sociology not only examines and studies social phenomena but, with its specificities, contributes to the analysis and study of the most human part of the social individual (living man). However, this implies an understanding of the mechanisms through which human beings take their decisions in a given situation. Exogenous attempts to change the behaviour of individuals without transforming their way of interacting remain unsuccessful. Interactions, therefore, should be oriented towards those altruistic relationships which, based on the ethic of responsibility, distinguish a free, harmonious, humanistic, and creative society.

Funding The realization of this paper was possible with the moral support (not with funds) of the affiliation institution of the author.

\section{Declarations}

Conflicts of Interest/Competing Interests Not applicable.

\section{References}

Aristotle. (2009). The Nicomachean Ethics (D. Ross, Trans.). Oxford, UK: Oxford University Press. (Original work published n.d.).

Beck, U. (1994). Riskante Freiheiten. Frankfurt an Main, Germany: Suhrkamp.

Cipriani, R. (2021). The other, altruism and empathy. Variety of prosocial behavior. The American Sociologist. https://doi.org/10.1007/s12108-021-09496-y

Coleman, J. S. (1990). Foundations of social theory. Cambridge, MA: The Belknap Press of Harvard University.

Douglas, M. (1970). Natural Symbols. Explorations in Cosmology. Penguin Books.

Douglas, M., \& Wildavsky, A. (1983). Risk and culture: An essay on the selection of technological and environmental dangers. University of California Press.

Dubar, C. (2003). La socialisasion: Construction des identités socailes et professionalles. Paris, France: Armand Colin.

Fuller, S. (2006). The New Sociological Imagination. Sage.

Fukuyama, F. (1995). Trust. The Free Press.

Gambetta, D. (1988). Trust: Making and Breaking Cooperative Relations. Basil Blackwell.

Griswold, W. (1994). Cultures and Societies in a Changing World. Pine Forge Press.

Guadarrama-González, P. (2021). Reseña. Emiliana Mangone: Beyond the Dichotomy between Altruism and Egoism. Society, Relationship and Responsibility, Information Age Publishing, Charlotte, NC, ISBN 978-1-62396-128-2, 2020, 228 Pp. Diálogos, 108, 176-182.

Gualda, E. (2021). Altruism, contributions to society. The American Sociologist. https://doi.org/10.1007/ s12108-021-09504-1

Hadj-Moussa, R. (2021). Thinking altruism or relationality at Stake. The Americna Sociologist. https://doi. org/10.1007/s12108-021-09495-Z

Jeffries, V., Johnston, B. V., Nichols, L. T., Oliner, S. P., Tiryakian, E., \& Weinstein, J. (2006). Altruism and social solidarity: Envisioning a field of specialization. The American Sociologist, 37(3), 67-83. https://doi.org/10.1007/s12108-006-1023-7 
Maldonado, C. E. (2020). Superar los dualismos en las ciencias sociales: Reseña del libro Beyond the Dichotomy Between Altruism and Egoism: Society, Relationship and Responsibility, de E. Mangone, Charlotte, NC: Information Age Publishing, pp. 1-228, ISBN 978-1-62396-128-2. Cultura Latinoamericana, 32(2), 263-268. https://doi.org/10.14718/CulturaLatinoam.2020.32.2.11

Mangone, E. (2017). Risk According to the Relational Theory of Society. Stan Rzeczy, 12, 261-276.

Mangone, E. (2020a). Beyond the Dichotomy between Altruism and Egoism. Society, Relationship and Responsibility. Charlotte, NC: Information Age Publishing Inc.

Mangone, E. (2020b). Towards a New Configuration of the Ego / Alter Relationship: The Rediscovery of Altruism. Revista Latinoamericana de Estudios sobre Cuerpos, Emociones y Sociedad, 34(12), 75-84.

Mangone, E. (2020c). The role of sociology in the promotion of actions aimed at social innovation in the Mediterranean area. Revista Española de Sociología, 29(1), 87-99. https://doi.org/10.22325/res. 2020.06

Mangone, E. (2021). The future after a pandemic and the ethics of responsibility. SN Social Sciences, 1, 25. https://doi.org/10.1007/s43545-020-00032-2

Mangone, E., \& Dolgov, A. (2020). Sorokin's altruistic creative love: Genesis, methodological issues, and applied aspects. Human Arenas, 3, 6-22. https://doi.org/10.1007/s42087-019-00058-w

May, T. \&, Perry, B. (2017). Reflexivity: The essential guide. London, UK: Sage.

Merton, R. K. (1968). Social Theory and Social Structure. The Free Press.

Mills, Wright C. (1959). The Sociological Imagination. Oxford University Press.

Mutti, A. (2007). Distrust. In Italian sociological association (ed.), Annual Review of Italian Sociology 2007 (pp. 47-63). Naples, Italy: Scriptaweb.it.

Nichols, L. T. (2005). Integralism and positive psychology: a comparison of Sorokin and Seligman. Catholic Social Science Review, 10, 21-40.

Nichols, L. T. (2012). North Central Sociological Association presidential address: Renewing sociology: Integral science, solidarity, and loving kindness. Sociological Focus, 45(4), 261-273.

Ossewaarde, M. (2007). Sociology Back to the Publics. Sociology, 41(5), 799-812.

Putnam, R. (1992). Making democracy work: Civic Traditions in Modern Italy. Princeton University Press.

Ricœur, P. (1992). Oneself as Another (K. Blamey, Trans.). Chicago, IL: The University of Chicago Press. (Original work published 1990).

Rusu, M. S. (2018). Theorizing love in sociological thought: Classical contributions to a sociology of love. Journal of Classical Sociology, 20(1), 3-20. https://doi.org/10.1177/1468795X17700645

Schwarz, M., Thompson, M. (1990). Divided We Stand. Redefining Politics, Technology and social Choice. Hemel Hempstead, UK: Harvester Wheatsheaf.

Solis-Gadea, H. R. (2005). The New Sociological Imagination: Facing the Challenges of a New Millennium. International Journal of Politics, Culture, and Society, 18(3-4), 113-122.

Sorokin, P. A. (1951). Amitology as an applied science of amity and unselfish love. In K. G. Specht (ed.), Soziologische Forschung in Unserer Zeit (pp. 277-279). Köln und Opladen, Germany: Springer Fachmedien Viesbaden.

Sorokin, P. A. (1954). The Ways and power of Love. Types, Factors and Techniques of Moral Transformation. Boston, MA: Beacon Press.

Sorokin, P. A. (1966). Sociological Theories of Today. Harper \& Row.

Thompson, M., Ellis, R., \& Wildavsky, A. (1990). Cultural Theory. Westview Press.

Touraine, A. (1995). Critique of modernity. (D. Macey, Trans.). Cambridge, MA: Basil Blackwell (Original work published 1992).

Weber, M. (1919). Geistige Arbeit als Beruf : vier Vorträge vor dem Freistudentischen Bund. Duncker \& Humblot.

Zyuzev N. (2020). Book Review: Mangone E. (2020) Beyond the Dichotomy between Altruism and Egoism: Society, Relationship and Responsibility. Charlotte, NC.: Information Age Publishing Inc. - p. 200. Zhurnal sotsiologii $i$ sotsialnoy antropologii [The Journal of Sociology and Social Anthropology], 23(5), 239-245 (in Russian). https://doi.org/10.31119/jssa.2020.23.5.10

Zyuzev N. (2021). Altruism and rational choice theory. The American Sociologist. https://doi. org/10.1007/s12108-021-09521-0

Publisher's Note Springer Nature remains neutral with regard to jurisdictional claims in published maps and institutional affiliations. 